\title{
Prevalence of Cryptosporidium Infection in Sheep in Iran
}

\author{
İran’ da Koyunlarda Cryptosporidium enfeksiyonu prevalansı
}

\section{Jamal Gharekhani ${ }^{1}$, Heidar Heidari², Mohammadreza Youssefi ${ }^{3}$}

1Department of Parasitology, Central Veterinary Laboratory, Iranian Veterinary Organization, Hamedan, Iran 2Department of Parasitology, Paraveterinary Faculty of Bu-Ali Sina University, Hamedan, Iran ${ }^{3}$ Department of Parasitology, Islamic Azad University of Babol, Babol, Iran

\begin{abstract}
Objective: Cryptosporidium is an important zoonotic parasite in humans and animals worldwide. This study was conducted to investigate the prevalence of Cryptosporidium infection in Iran.

Methods: Fecal samples ( $n=1.749)$ were collected randomly in asymptomatic sheep from different rural regions of Iran in 2011 to 2012 . All samples were examined by using the cold modified Ziehl-Neelsen staining technique.

Results: Oocysts of Cryptosporidium was found in 11.3\% (198/1749) of samples $(9.8<\mathrm{Cl} 95 \%<12.8)$. There was a statistical differences among Cryptosporidium infection, age groups $(p<0.0001)$, and gender $(p=0.02)$.

Conclusion: This study is the first report of Cryptosporidium infection in sheep in different regions of Iran. Therefore, further comprehensive molecular studies in sheep to identify the source of contaminations (animals or humans) and designing control strategies is highly recommended. (Turkiye Parazitol Derg 2014; 38: 22-5)
\end{abstract}

Key Words: Cryptosporidium, prevalence, sheep, Iran

Received: 26.10 .2013

Accepted: 27.12 .2013

\section{ÖZET}

Amaç: Cryptosporidium, dünya çapında, insanlarda ve hayvanlarda önemli bir zoonotik parazittir. Bu çalışma İran'da Cryptosporidium enfeksiyonu prevalansını araştırmak amacıyla yapıldı.

Yöntemler: 2011-2012'de İran'ın farklı kırsal bölgelerinden asemptomatik koyunlardan rastgele dışı örnekleri (n=1749) toplandı. Tüm örnekler soğuk modifiye Ziehl-Neelsen boyama tekniği kullanılarak incelendi.

Bulgular: Cryptosporidium oocyst'leri örneklerin \%11,3'ünde (198/1749) bulundu $(9,8<\mathrm{Cl} 95 \%<12,8)$. Cinsiyet $(p=0,02)$ ve yaş grupları arasında ( $p<0,0001)$ Cryptosporidium enfeksiyonu açısından istatistiksel farklılık mevcuttu.

Sonuç: Bu çalışma, İran'ın farklı bölgelerinde koyunlarda Cryptosporidium enfeksiyonu hakkında ilk rapordur. Bu nedenle, kontaminasyonların (hayvanlar veya insanlar) kaynağını belirlemek ve kontrol stratejilerini tasarlamak için koyunlarda daha kapsamlı moleküler çalışmalar şiddetle tavsiye edilir. (Turkiye Parazitol Derg 2014; 38: 22-5)

Anahtar Sözcükler: Cryptosporidium, prevalans, koyun, Iran

Geliş Tarihi: 26.10.2013

Kabul Tarihi: 27.12.2013

Address for Correspondence / Yazışma Adresi: Heidar Heidari, Janbazan street, Postal Box: 65167, Paraveterinary Faculty of BuAli Sina university, Hamedan, Iran Phone: +(98) 8114227350 E-mail: heidari346@basu.ac.ir DOI:10.5152/tpd.2014.3224

CCopyright 2014 Turkish Society for Parasitology - Available online at www.tparazitolderg.org

CTelif hakkı 2014 Türkiye Parazitoloji Derneği - Makale metnine www.tparazitolderg.org web sayfasından ulaşılabilir. 


\section{INTRODUCTION}

Cryptosporidium is an important zoonotic parasite in humans, domestic and wild animals such as mammals, birds, reptiles and fish (1). The distribution of this parasite is worldwide, and commonly is found in warm and wet seasons $(2,3)$.

Cryptosporidium was first described affecting in mice by Tyzzer in 1907 (4). In sheep, cryptosporidiosis was first described in lambs with diarrhea in Australia in 1974 (5). Also, cryptosporidiosis was first found in a native rooster in Iran in 1985 (6).

A single oocyst is sufficient to produce infection in susceptible hosts. Oocysts are most commonly transmitted by the fecaloral route through direct host-to-host contact, and indirect contamination of food or water; although aerosol transmission of oocysts has also been reported (7). Zoonotic transmission has been confirmed by epidemiological investigations such as pets, farm animals and by accidental infection of veterinary workers (3, 7-9).

Cryptosporidiosis is commonly self-limiting in the immunocompetent hosts (7). Young animals appear to be more sensitive to disease, while infections in adult animals are often asymptomatic or do not occur $(1,7,10)$. In sheep, cryptosporidiosis is presented as a mild to severe yellowish liquid diarrhea with a strong odor, weight loss, depression, abdominal pain, and death usually involving animals up to one month of age $(7,11,12)$.

Cryptosporidiosis may have significant economic losses in animal husbandry. Additionally, infected animals pose a health risk to humans given the zoonotic potential of this parasite, which continues to cause a serious and life-threatening disease in immunodeficient patients such as $\operatorname{AIDS}(1,7)$.

Different methods have been developed to diagnosis of Cryptosporidium. The most common method of them involves oocysts detection using fecal smears examination with ZiehlNeelsen staining $(7,13)$. The molecular techniques have been also used to identify Cryptosporidium in feces of sheep in some countries $(12,14)$.

There is little information regarding the occurrence of cryptosporidium infection in sheep and other hosts in different regions of Iran $(8,9,15,16)$. Also, there is no published comprehensive information of Cryptosporidium prevalence in sheep in this area.

The principal aim of current study was to obtain the prevalence of Cryptosporidium infection in sheep in Iran.

\section{METHODS}

\section{Study Area}

Iran lies between latitudes $24^{\circ}$ and $40^{\circ} \mathrm{N}$, and longitudes $44^{\circ}$ and $64^{\circ} \mathrm{E}$ is located in Middle-East, Asia. It covers an area of $1,648,195 \mathrm{~km}^{2}$ by different climate ranges including cool mountainous areas in West, rainfall and temperate plains in North, arid and desert in Central, and tropical area in South of Iran. This country is economically important for crops and animal husbandry, such as sheep breeding. In Iran, the sheep population is estimated to be at 50 millions according to Iranian Veterinary Organization (IVO) report in 2010.

\section{Sample Collection and Examination}

1,749 stool samples were collected randomly in sheep without clinical signs in different rural regions of Iran from 2011 to 2012 in cross-sectional study; kept under the semi-intensive feeding system (Table 1). A sample was taken from the rectum by using a disposable plastic bag for each animal, which were fixed quickly in $10 \%$ formalin until the examination. All samples were concentrated by formalin-ether technique and examined for microscopy (100X) using cold modified Ziehl-Neelsen staining (3).The Cryptosporidium oocysts were observed as spherical red colored objects, around 4-5 $\mu \mathrm{m}$ in diameter, with internal structures somehow crescent shape (3).

\section{Statistical analysis}

Chi-square test $\left(\mathrm{X}^{2}\right)$ was used to compare infection rates between different age groups and gender. Odds ratios (OR), confidence interval $(\mathrm{Cl}), \mathrm{X}^{2}$ and $\mathrm{p}$-value were calculated separately for each variable. $p$-value of less than 0.05 was considered statistically significant.

\section{RESULTS}

Oocysts of Cryptosporidium was found in 11.3\% (198/1749) of samples $(9.8<\mathrm{Cl} 95 \%<12.8)$. There was a statistical differences among Cryptosporidium infection, age groups $\left(x^{2}=23.929\right.$, $p<0.0001, D F=1, O R=2.1)$, and gender $\left(x^{2}=5.385, p=0.02, D F=1\right.$, $O R=1.4)$. The detailed information of different regions is summarized in Table 1-3.

\section{DISCUSSION}

Cryptosporidiosis is a common cause of diarrhea in humans and animals worldwide (7). The economic losses were incurred due to Cryptosporidium infections in livestock and the threat to human health are major concerns. Therefore prevention and control measures need to be adopted and regulated in the animal environment. Veterinarians have an important role to recog-

Table 1. Prevalence of Cryptosporidium infection in different location

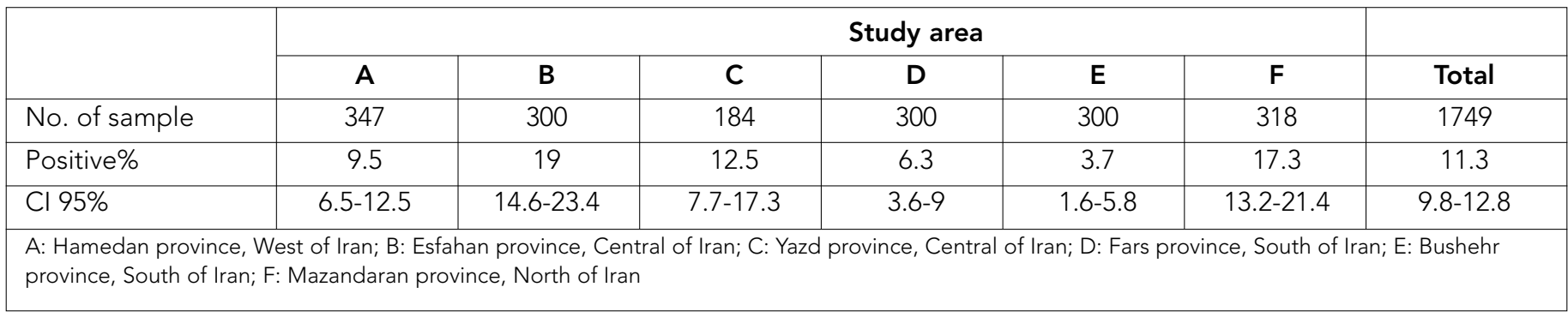


Table 2. Prevalence of Cryptosporidium infection in different location

\begin{tabular}{|l|c|c|c|c|c|c|c|}
\hline \multirow{2}{*}{$\begin{array}{l}\text { Age groups } \\
\text { (year) }\end{array}$} & \multicolumn{7}{|c|}{$\begin{array}{c}\text { Study area } \\
\text { No. of sample (Positive \%) }\end{array}$} \\
\cline { 2 - 8 } & A & B & C & D & E & F & Total \\
\hline$\leq 1$ & $132(13.6)$ & $138(23.9)$ & $19(21.1)$ & $114(0.88)$ & $52(17.3)$ & $100(19)$ & $555(16.7)$ \\
\hline$>1$ & $215(6.98)$ & $162(14.8)$ & $165(11.5)$ & $186(4.8)$ & $248(0.8)$ & $218(16.5)$ & $1194(8.8)$ \\
\hline P-value & 0.04 & 0.04 & 0.233 & 0.174 & $<0.0001$ & 0.586 & $<0.0001$ \\
\hline $\begin{array}{l}\text { A: Hamedan province, West of Iran; B: Esfahan province, Central of Iran; C: Yazd province, Central of Iran; D: Fars province, South of Iran; E: Bushehr } \\
\text { province, South of Iran; F: Mazandaran province, North of Iran }\end{array}$ \\
\hline
\end{tabular}

Table 3. Prevalence of Cryptosporidium infection in different gender groups

\begin{tabular}{|l|c|c|c|c|c|c|c|}
\hline \multirow{2}{*}{ Gender } & \multicolumn{7}{|c|}{ Study area } \\
No. of sample (Positive \%) \\
\cline { 2 - 8 } \\
\cline { 2 - 8 } & A & B & C & D & E & F & Total \\
\hline Female & $125(8.8)$ & $70(24.3)$ & $34(17.6)$ & $73(9.6)$ & $37(5.4)$ & $116(18.9)$ & $455(14.3)$ \\
\hline p-value & $222(9.9)$ & $230(17.4)$ & $150(11.3)$ & $227(5.3)$ & $263(3.4)$ & $202(16.3)$ & $1294(10.3)$ \\
\hline $\begin{array}{l}\text { A: Hamedan province, West of Iran; B: Esfahan province, Central of Iran; C: Yazd province, Central of Iran; D: Fars province, South of Iran; E: Bushehr } \\
\text { province, South of Iran; F: Mazandaran province, North of Iran }\end{array}$ \\
\hline
\end{tabular}

nize emerging disease and apply strategies to prevention and control of infections (17).

To increase our knowledge of the parasite's epidemiology, biology, taxonomy, and molecular diversity, extensive research is needed, as are improved detection protocols capable of differentiating species and genotypes. Understanding the biological behavior and correctly identifying the offending Cryptosporidium spp. will be critical if the intervention and control strategies are to be effective (7).

The prevalence of Cryptosporidium infection was reported $4 \%$ to $85 \%$ in sheep worldwide (18). Previous investigations conducted on the prevalence of Cryptosporidium in sheep based on microscopy have reported prevalences ranging from $0 \%$ in Ethiopia, 2.6\% in Autralia, 3.7\%-47\% in Brazil, $13.6 \%-46.5 \%$ in Turkey, $25.7 \%$ in Mexico, $29 \%$ in Greece, and $42.1 \%$ in Serbia $(1,2,10,12,13,17,19,20-22)$. In Iran, this rate was reported separately $4 \%$ in North, $13.8 \%$ in Central, $2.5 \%$ and $8.6 \%$ in West, $9.2 \%$ and $28.6 \%$ in Capital regions $(3,8,9$, $18,23)$.

In this study, the infection rate was partly similar to the study done in Poland (10.1\%) and partly different to studies taken in the other countries (24). Also, infection rate in rainfall area (17.3\% in Mazandaran province) was higher than the other regions (Table 1); it is agreement consistent with previous reports (2). Different of hygiene conditions and management in farms, study design, methods, climates and different geographical regions may be the main cause of varied results $(1,7)$.

In our study, the infection rate in $\leq 1 \mathrm{yr}$ animals $(16.7 \%, \mathrm{p}<0.000$, $\mathrm{OR}=2.1$ ) was found higher than $>1 \mathrm{yr}(8.8 \%)$; the results are consistent with those of other researchers reporting a strong correlation $(p<0.05)$ between the age and infection $(1,8-10,12$, $17-19,24)$. In contrast to finding of this study, there was a close association $(p>0.05)$ between infection and age groups in asymptomatic adult sheep from Mexico (13).

Age is the major risk factor in spreading of cryptosporidiosis (19); and risk of infection and morbidity are greater in neonatal animals (21). Increasing prevalence rate in low age groups may be due to immature immune system and their sensitivity against infection (18).

In this study, infection rate was reported $14.3 \%$ in male $(p=0.02$, $O R=1.4$ ) and $10.3 \%$ in female animals; the finding is opposite to the other investigations $(3,8,9,23)$.

In current study, Cryptosporidium infection was asymptomatic in all animals. The prevalence of Cryptosporidium in healthy sheep implies that they can serve as reservoirs of the infection (21).

In Iran, the most sheep breeding farms are traditional and the sheep have direct contacts with other animals. It is also possible that the quality of zoohygienic conditions of animal husbandry and grazing practices influences the exposure of animals to cryptosporidial infection.

Due to the great morphological similarity among species of Cryptosporidium, utilizing of microscopic observation of oocysts alone is not sufficient for identification of species (12).

\section{CONCLUSION}

This study is the first report of Cryptosporidium infection in sheep in different regions of Iran. Therefore further comprehensive molecular studies in sheep cryptosporidiosis to identify the source of contaminations (animals or humans) and designing control strategies is highly recommended. 
Ethics Committee Approval: Ethics committee approval was received for this study from the ethics committee of Bu-Alisina university, faculty of Paraveterinary (2010-207).

Informed Consent: Not required in this study.

Peer-review: Externally peer-reviewed.

Author Contributions: Concept - J.G., H.H.; Design - J.G., H.H.; Supervision - H.H.; Funding - J.G., H.H.; Materials - J.G., M.Y.; Data Collection and/or Processing - J.G., M.Y.; Analysis and/or Interpretation - J.G.; Literature Review - J.G., H.H.; Writing - J.G., H.H.; Critical Review - J.G., H.H., M.Y.

Conflict of Interest: No conflict of interest was declared by the authors.

Financial Disclosure: The authors declared that this study has received no financial support.

Etik Komite Onayı: Bu çalışma için etik komite onayı Bu-Alisina University, Faculty of Paraveterinary'den alınmıştır (2010-207)

Hasta Onamı: Bu çalışmada gerekmemektedir.

Hakem değerlendirmesi: Dış bağımsız.

Yazar Katkıları: Fikir - J.G., H.H; Tasarım - J.G., H.H.; Denetleme - H.H.; Kaynaklar - J.G., H.H.; Malzemeler - J.G., M.Y.; Veri toplanması ve/veya işlemesi - J.G., M.Y.; Analiz ve/veya yorum J.G.; Literatür taraması - J.G., H.H.; Yazıyı yazan - J.G., H.H.; Eleştirel inceleme - J.G., H.H., M.Y.

Çıkar Çatışması: Yazarlar çıkar çatışması bildirmemişlerdir.

Finansal Destek: Yazarlar bu çalışma için finansal destek almadıklarını beyan etmişlerdir.

\section{Acknowledgment}

We greatly appreciate the staff members of Parasitology Laboratory of Paraveterinary faculty, Bu-Ali Sina University for kindly help. This study has not been supported by any foundation.

\section{REFERENCES}

1. Ulutas B, Voyvoda H. Cryptosporidiosis in diarrhoeic lambs on a sheep farm. Turkiye Parazitol Derg 2004; 28: 15-7.

2. Green RE, Amarante AFT, Mascarini LM. The seasonal distribution of Cryptosporidium oocysts in sheep raised in the state of São Paulo. Rev Bras Parasitol Vet 2004; 13: 125-7.

3. Jafari R, Maghsood AH, Fallah M. Prevalence of Cryptosporidium infection among Livestock and Humans in contact with Livestock in Hamadan District, Iran, 2012; J Res Health Sci 2013; 13: 88-9.

4. Tyzzer EE. A sporozoan found in the peptide glands of the common mouse. Proc Soc Exp Biol Med 1907; 5: 12-3. [CrossRef]

5. Barker IK, Carbonell PL. Cryptosporidium agni sp.n. from lambs, and Cryptosporidium bovis sp.n. from a calf, with observations on the oocyst. Z Parasitenk 1974; 44: 289-98. [CrossRef]
6. Gharagozleu MJ, Khodashenas M. Cryptosporidiosis in a rooster with a chronic prolifrative Enteritis Arch. Vet J 1985; 4: 129-38.

7. Ramirez NE, Ward LA, Sreevatsan S. A review of the biology and epidemiology of cryptosporidiosis in humans and animals. Microb Infec 2004; 6: 773-85. [CrossRef]

8. Mokhber-Dezfouli MR, Meshgi B. Epidemiological study of cryptosporidial infestation of man and animals. J Vet Res 2002; 57: 87-92.

9. Heidari H, Gharakhani J. Study of Cryptosporidium infection in the Livestock (Cattle, Sheep, Dogs, Fowls) and Humans, in Hamadan City and its Suburbs during 2006-2011. Sci J Hamadan Univ Med Sci 2012; 19: 67-74.

10. Ozdal N, Tanritanir P, Goz Y, Deger S, Kozat S. Parasitic protozoans (Eimeria, Giardia, and Cryptosporidium) in lambs with diarrhoea in the Van province, Turkey. Bull Vet Inst Pulawy 2009; 53: 47-51.

11. Castro-Hermida JA, Gonzalez-Warleta M, Mezo M. Natural infection by Cryptosporidium parvum and Giardia duodenalis in sheep and goats in Galacia (NW Spain). Small Rumin Res 2007; 72: 96-100. [CrossRef]

12. Silva-Fiuza VR, Juliboni-Cosendey RI, Frazao-Teixeira E, Santín M, Ronald Fayer, Rodrigues-Oliveira FC. Molecular characterization of Cryptosporidium in Brazilian sheep. Vet Parasitol 2011; 175: 360-2. [CrossRef]

13. Fresan MUA, Oaxaca JS, Ordonez VV. Cryptosporidium spp. prevalence in lambs and ewes from the Northern region in the state of Mexico. Int Soc Anim Hygi 2004; 2: 419-20.

14. Quilez J, Torres E, Chalmers RM Hadfield SJ, Cacho ED, Sanchez-Acedo C. Cryptosporidium Genotypes and Subtypes in Lambs and Goat Kids in Spain. Appl Environ Microbiol 2008; 74: 6026-31. [CrossRef]

15. Ahourai P, Ezzi A, Gholami MR, Vandyoosefi J, Kargar R, Maalhagh N. Cryptosporidium spp. in new born lambs in Iran. Trop Anim Health Prod 1985; 17: 6-8. [CrossRef]

16. Nouri M, Karami M. Asymptomatic cryptosporidiosis in nomadic shepherds and their sheep. J Infect 1991; 23: 331-3. [CrossRef]

17. Zorana M, Sofija KR, Kuli Z. Cryptosporidium infection in Lambs and Goat Kids in Serbia. Acta Vet 2006; 56: 49-54. [CrossRef]

18. Fasihi-Harandi M, Fotohi-Ardakani R. Cryptosporidiosis infection of sheep and goats in Kerman: epidemiology and risk factor analysis. $J$ Vet Res 2008; 63: 47-51.

19. Sari B, Arslan MO, Gicik Y, Kara M, Taşçi GT. The prevalence of Cryptosporidium species in diarrhoeic lambs in Kars province and potential risk factors. Trop Anim Health Prod 2009; 41: 819-26. [CrossRef]

20. Ryan UM, Bath C, Robertson I, Read C, Elliot A, Mcinnes L, et al. Sheep may not be an important zoonotic reservoir for Cryptosporidium and Giardia Parasites. App Envir Microbiol 2005; 71: 4992-7. [CrossRef]

21. Panousis N, Diakou A, Giadinis N, Papadopoulos E, Karatzias H, Haralampidis S. Prevalence of Cryptosporidium infection in Sheep flocks with a history of Lambs' Diarrhoea. Rev Med Vet 2008; 159: 528-31.

22. Ayana D, Tilahun G, Wossene A. Study on Eimeriaand Cryptosporidium infections in Sheep and Goats at Elfora export Abattoir, DebreZeit, Ethiopia. Turk J Vet Anim Sci 2009; 33: 367-71.

23. Vahedi N, Dalimi-Asl A, Saadat M. Primary research on Gastro-Intestinal Cryptosporidium incidence rate in Lambs and Calves in Amol city, Iran. J Vet Res 2009; 64: 101-2.

24. Majewska AC, Werner A, Sulima P, Luty T. Prevalence of Cryptosporidium in sheep and goats bred on five farms in west-central region of Poland. Vet Parasitol 2000; 89: 269-75. [CrossRef] 